\title{
Financial Recovery Organization on the Basis of Cash Flow Management
}

Ajupov A.A.

Kazan Federal University, Institute of Management, Economics and Finance, Kazan, 420008, Russia

Kurilova A.A.

Togliatti State University, Togliatti, 445667, Russia

Kovalenko O.G.

Togliatti State University, Togliatti, 445667, Russia

Emai: aakurilova@yandex.ru

\section{Doi:10.5901/mjss.2015.v6n3p710}

\section{Abstract}

The article contains a group of guidelines that will enable enterprises in a crisis to seek additional funds for financial recovery of the organization. In the system of financial recovery is first necessary to actively use it for internal reserves of financial stabilization. To maintain the liquidity of the company in the short term in a crisis, it is necessary to increase the cash flow. The article deals with activities that will increase the amount of money in the enterprise.

Keywords: financial management, crisis, cash flow, financial improvement.

\section{Introduction}

The impact of constantly changing factors in the external economic environment and internal conditions of financial activity periodically cause negative consequences in its functioning. One reason for this is the impact of the financial crisis of bearing the greatest threat to its development and requiring financial recovery.

In a market economy, the cash flows of the enterprise are always the most limited resource, so the effective cash flow management ensures its financial stability. This is due to the fact that due to the unevenness of receipts and payments, or as a result of unforeseen circumstances, the organization may be problems associated with the execution of the current liabilities. Lack of analytical information, to identify the reasons for this state of money in the end, can lead to total insolvency. Moreover, at the present stage of development of the economy in general and industry in particular, the factors affecting their financial condition, so multifaceted that objectively pushed to the need to find new ways of financial recovery organizations.

High role in the financial restructuring of the organization on the basis of cash flow is determined by the fact that they serve the implementation of its economic activity in almost all aspects. Efficient formation of the cash flow improves rhythm implementation of the operational process. Effective crisis financial cash flow management allows organizations to reduce the need for borrowed capital. Actively managing cash flow, can provide a more rational and economical use of their own financial resources generated from domestic sources to reduce dependence on the rate of development of the enterprise involved loans mitigate risk of insolvency of an economic entity. Active forms of cash management have enabled the company to obtain additional income generated directly by the monetary asset. It is, first and foremost, on the effective use of temporarily idle cash balances in current assets, as well as the mobilization of additional resources in the implementation of financial investments.

Relevance and insufficient elaboration of a number of aspects of the financial health of the organization on the basis of cash flow management determined the choice of the theme of the article.

The purpose of research is to develop theoretical and practical approaches to the financial health of the commercial organizations on the basis of cash flow in terms of the current stage of market transformation of the Russian economy.

Theoretical and methodological basis of the study are the materials contained in the scientific works of Russian and foreign economists on the theory of financial recovery, crisis financial management, financial management, basic and 
applied research on cash management in the enterprise.

For the reliability of research findings in the study used data obtained from a sample survey of enterprises and materials published in periodicals.

\section{Theory}

In recent years, the system of financial management of crisis now more and more attention is paid to the organization of the cash flows that have a significant impact on the final results of its business activities.

In the study, cash flow can be treated as a "distribution in time sequence of income (inflow) and expenditures (outflow) generated during the time horizon of the operations or other object in a certain scale," and the anti-crisis financial management can be considered a management aimed at preventing or overcoming the adverse financial and economic activity of the enterprise through the use of the complex phenomena of administrative decisions, the development and implementation of a special program that has tactical and strategic, allowing to eliminate the time and trouble to maintain their position in the market.

Restoring fiscal balance of the enterprise and to minimize loss of its market value caused by the financial crisis the main goal of the anti-crisis financial management, and the generation of cash flows is one of the most important signs of financial stability.

Cash is the most liquid part of current assets. At the same time - this is a limited resource, so important is the creation of an effective mechanism in the enterprise cash management in terms of its financial recovery.

The main objects of cash management are:

a) a positive cash flow (cash inflow) - characterizes the set of cash flows to the company of all kinds of business transactions;

b) a negative cash flow (cash outflow) - characterizes the aggregate cash payments now in the implementation of all kinds of business transactions. These types of cash flows linked. Insufficient amount of time one of these flows determines their subsequent decline in another species;

c) clean (free) cash flow, which is defined as the difference between positive and negative cash flows (between the receipt and expenditure of funds) in the period under consideration in the context of its individual intervals. Depending on the ratio of the volume of the positive and negative flows of the sum of net cash flow can be characterized by both positive and negative, affecting ultimately the formation of the size of the balance of monetary assets (holdings);

d) cash balance on the current account or in cash.

In the course of the anti-crisis fiscal cash management to address the following critical issues: the balance of the volumes of cash flows; synchronization of cash flows over time; maximizing positive cash flow, which implies growth of inflow velocity or cash flows; minimization of negative cash flow, which is a decrease in the volume of outflows or slowing the rate of outflows; maximization of net cash flow for further optimization (minimization) of the average balance of funds for a certain period of time; circuit implementation of monetary assets, their smooth and rapid flow of from one form to another; increase the return on invested funds by capitalization of profits and reduce financial risks.

\section{Results}

Offer key recommendations of management impacts associated with the cash flows for the purpose of financial rehabilitation of enterprises.

To maintain the company's liquidity in the short term, in terms of financial improvement is necessary to increase the cash flow. This can be achieved by means of measures relating to the management of cash flows, which should be divided into methodological and organizational depending on the nature of their impact on the financial system (Figure 1).

Arrangements financial recovery, in our view, represent a set of actions aimed at improving the efficiency of cash management and organizational development financially unstable companies to implement their financial recovery. They are associated with the reorganization of the management of the enterprise.

Activities having a methodical nature of its cash management in the financial recovery of the enterprise are the various techniques and methods of influence on the financial system in order to restore its function and eliminate signs of crisis.

Methodical and organizational arrangements in the management of cash flow on the financial recovery of the enterprise in a given situation can be combined or used individually.

These recommendations have the practical significance and determine the typical scheme of management actions 
on the individual elements of the business processes of enterprises for the production of automotive components.

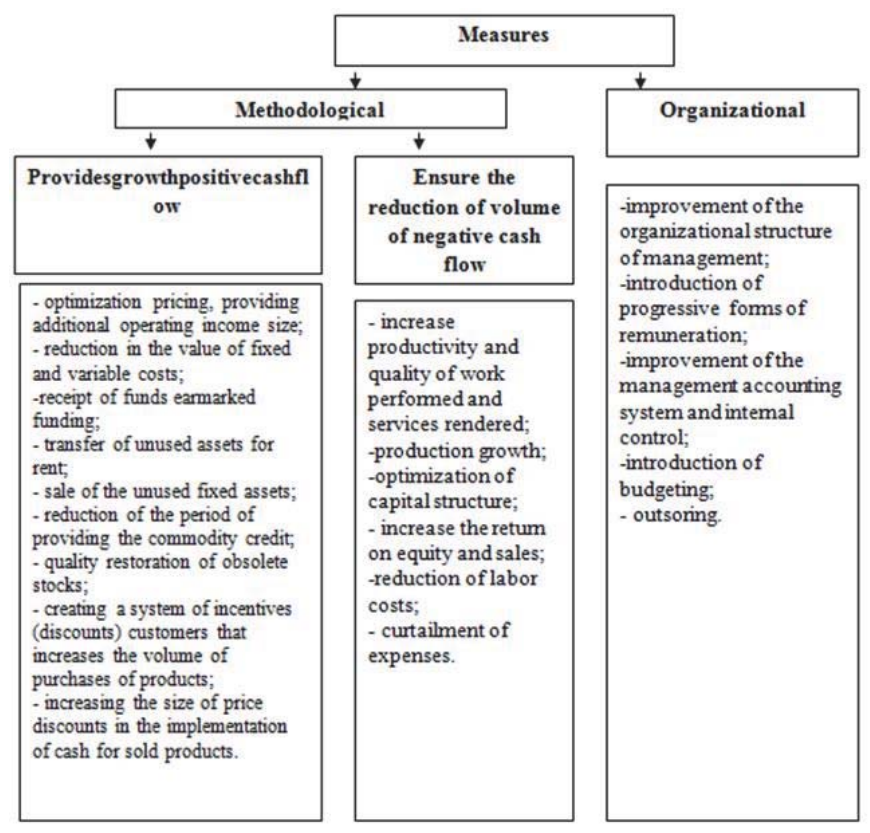

Fig. 1 System management activities in the cash flows of the financial health of the organization to manage cash flows in the financial health of the organization

Few economists, considering the cash flow management, and giving recommendations on this matter, paying attention, and sometimes even ignore such options of management actions in order to financial recovery, how to improve the system of accounting (preparation of tax calendar, the introduction of information-processing programs accounting documents, etc.) and improvement of the organization management (creation of new functional units responsible for the company's financial recovery, dismissal or low-skilled managers improve their skills, implementation of effective information support, improved production and management organizational structure, etc.) .

In our view, the omission seems to be such "minor" measures could lead to a financial crisis of the enterprise. Therefore, we believe that a number of recommendations relating directly to production and business activities of the enterprise and should be paid great attention to the management of the organization.

\section{Conclusions}

From the positions of the anti-crisis knowledge cash flow management company acts as a multi-purpose tool and allows, in our opinion, to establish whether the company is capable of in the process of formation and use of financial resources to ensure the sustainability of the production and sales of products in compliance with the financial and payment discipline. Therefore, attention to the financial aspects of the life of the enterprise, we believe, allows management to make major strategic financial decisions, and promptly identify the various faults and omissions in the current work, the critical terms of the probability of loss of financial viability.

The emergence of the financial crisis, the company is always associated with the violation and failure management mechanism in the "peaceful" conditions and this can serve as the negative impact of external and internal environmental factors.

The introduction of the anti-crisis financial management of cash flows at the company said, in our view, primarily two things. Either the company employs highly qualified and competent financial management, which has aimed to predict and protect themselves from the financial crisis, or the company has already had such a situation, where there were the first failures in the management of cash flow, which led to the crisis.

As a result of the proposed actions for management of cash flows in the financial recovery of the enterprise will receive the following economic benefits:

- an increase in productivity and quality of work performed and services rendered; 
- increase in production;

- optimization capital structure;

- increase return on equity and sales;

- reduction of costs;

- reduction of administrative costs;

- increase the individual responsibility of management personnel for the results of work and the quality of the management system;

- increase efficiency in the use of the equity capital of the enterprise;

- optimization organizational structure of financial management;

- formation financial organizational subcultures.

The obtained results of the study concerning the development of methodological and theoretical approaches, practical tools cash management system in terms of financial recovery can be actively used in enterprises in order to prevent a crisis in the enterprise. And as the results show that the generation of cash flows is one of the most important signs of financial stability.

\section{References}

Ficbauer, D.Specifics of financial management of holdings when managing cash-flow // ActaUniversitatisAgriculturae et SilviculturaeMendelianaeBrunensis6 (2), 2010, p.p. 673-680

He, Y., Dai, B. Document The research on the financial early warning system based on cash flow // Proceedings of the International Conference on E-Business and E-Government, ICEE 2010, p.p. 4943-4947

Kroes, J.R., Manikas, A.S. Cash flow management and manufacturing firm financial performance: A longitudinal perspective // International Journal of Production Economics, 2014, p.p. 37-50

Lien, D., Yu, C.-F.(J.) Time-inconsistent investment, financial constraints, and cash flow hedging // International Review of Financial Analysis, 2014

Sysoyeva, L., Buriak, A. Development prerequisites for the regulatory approaches of the systemic risk regulation in finances//Source of the Document Economic Annals-XXI, 1-2 (2), 2014, p.p. 20-23.

Thiruvady, D., Wallace, M., Gu, H., Schutt, A. A lagrangian relaxation and ACO hybrid for resource constrained project scheduling with discounted cash flows // Journal of Heuristics, 2014

Yu, F., Zeng, Y. Corporation value based on free cash flow // DianziKejiDaxueXuebao/Journal of the University of Electronic Science and Technology of China 35 (1), 2006, p.p. 140-143

Yongtao Hong, FarizHuseynov and Wei Zhang. Earnings Management and Analyst Following: A Simultaneous Equations Analysis//Financial Management, Summer 2014, Volume 43, Issue 2, p.p. 355-390.

Valitov S.M., Nigmetzyanov A.A. Modern principles of financial services markets regulation as a response to the financial and economic crisis of 2008 // Mediterranean Journal of Social Sciences vol. 5 № 24, November 2014, pp. 285-293.

Yartiev A.F., Tufetulov A.M. Effect of license holder's cost-flow on long-term development of oil industry // Mediterranean Journal of Social Sciences vol. 5 № 24, November 2014, pp. 417-420

Safiullin M.R., Safiullin A.R. Structural analysis of the dynamics of petrochemical cluster of Republic Tatarstan // Mediterranean Journal of Social Sciences vol. 5 № 24, November 2014, pp. 300-306. 